\title{
The Dust Bowl
}

\author{
Connie Nugent MLS
}

Overly aggressive farming practices coupled with drought provided a "perfect storm" that created the devastating effects of the Dust Bowl of the 1930s. Increased immigration to the Midwest led to intense cultivation of the grasslands that had protected the topsoil; increased prices for wheat encouraged farmers to overextend themselves without regard to proper land management. As rainfall dwindled, the prevailing winds roared across the prairies, smothering farms with fine gritty dust. Texas painter Alexandre Hogue deplored this disaster, holding mankind responsible for the effects of the Dust Bowl depicted in his Erosion Series of paintings (1933-36).

In her novel Out of the Dust, Karen Hesse presents in verse the experiences of a farm family in 1930s Oklahoma. In one passage, she could be describing the subject of a painting by Hogue. In the story, a farmer can no longer afford to feed his cows nor can he sell them, so the County Agent sacrifices them,

"Too hard to / watch their lungs clog with dust,

Like our chickens, suffocated.

Better to let the government take them

Than suffer the sight of their bony hides

Sinking down / into the earth."1

This stanza evokes Hogue's 1936 painting Drought Survivors, in which dust piles up across fences, partly buries a tractor, and has suffocated two cows, whose "bony hides [sink] down into the earth." Only a rattlesnake and a prairie dog still live. According to art historian Lea Rossen DeLong, the irony is palpable, since those two animals "were exactly the two creatures most despised by the farmers trying to cultivate the plains." Hogue's painting illustrates the "Path of Our Sorrow"

Corresponding author: Connie Nugent

Contact Information: Connie.nugent1@gmail.com DOI: 10.12746/swrccc.v6i22.432

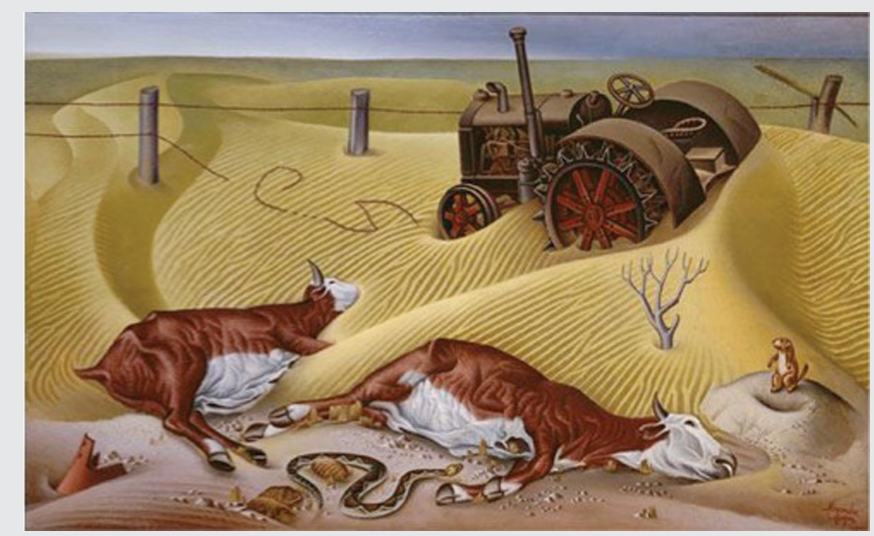

Figure. Alexandre Hogue, Drought Survivors, 1936, (formerly Musée National D’Art Moderne, Paris. Destroyed by fire in 1948.) Accessed: 12/27/2017. https://picturingmeteorology.com/home/2017/3/6/ drought-survivors-1936.

presented in Out of the Dust: the tractor represents the over-mechanization of farming and the basic mismanagement of the land that contributed to the disaster that was the Dust Bowl. Hogue places the tractor above the emaciated cows to represent the dominance of technology, but it serves merely as a tombstone. ${ }^{2}$ Farmers and ranchers used barbed wire to define boundaries, to claim ownership of their land. In Drought Survivors, the wire lies broken, partly submerged by dunes of dust; nature has won this battle. When Life Magazine published in 1937 the Erosion Series accompanied by photographs of the Dust Bowl, it "revealed the dramatic destruction of the rural world."

Keywords: Dust Bowl, 1930s, Central Plains states, economic depression

From: Department of Internal Medicine, Texas Tech University Health Sciences Center, Lubbock, TX

Submitted: $12 / 27 / 2017$

Conflicts of interest: none 


\section{REFERENCES}

1. Hesse K. Out of the Dust. New York: Scholastic, 1997. p. 102.

2. Hartvigsen AK. "The Terrifying and the Beautiful: an Ecocritical approach to Alexandre Hogue's Erosion Series. All Theses and Dissertations. 5695. P.23. http://scholarsarchive.byu.edu/ etd/5695.

3. Picturing Meterology: Images of Science and History. March 7, 2017. 